\title{
Research of Impacts of the 2018 Hokkaido Eastern Iburi Earthquake on Sediment Transport in the Atsuma River Basin Using the SWAT Model
}

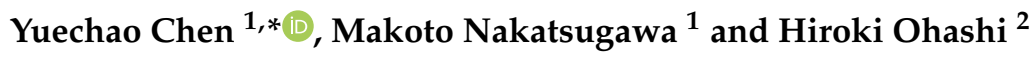 \\ 1 Water Environment System laboratory, Muroran Institute of Technology, Mizumoto 27-1, \\ Muroran 050-8585, Japan; mnakatsu@mmm.muroran-it.ac.jp \\ 2 OYO Corporation, Kanda Midoshiro 7, Chiyoda, Tokyo 101-8486, Japan; oohashi-hiroki@oyonet.oyo.co.jp \\ * Correspondence: 19096505@mmm.muroran-it.ac.jp; Tel.: +81-070-4020-6754
}

Citation: Chen, Y.; Nakatsugawa, M.; Ohashi, H. Research of Impacts of the 2018 Hokkaido Eastern Iburi Earthquake on Sediment Transport in the Atsuma River Basin Using the SWAT Model. Water 2021, 13, 356. https://doi.org/10.3390/w13030356

Academic Editor: Kazimierz Banasik Received: 30 October 2020

Accepted: 27 January 2021

Published: 30 January 2021

Publisher's Note: MDPI stays neutral with regard to jurisdictional claims in published maps and institutional affiliations.

Copyright: (C) 2021 by the authors. Licensee MDPI, Basel, Switzerland. This article is an open access article distributed under the terms and conditions of the Creative Commons Attribution (CC BY) license (https:// creativecommons.org/licenses/by/ $4.0 /)$.

\begin{abstract}
Landslides, debris flows, and other secondary disasters caused by earthquakes threaten the safety and stability of river basins. Earthquakes occur frequently in Japan. Therefore, it is necessary to study the impact of earthquakes on sediment transport in river basins. In this study, considering the influence of reservoirs, the Soil and Water Assessment Tool-calibration and uncertainty program (SWAT-CUP) was employed to analyze the runoff parameter sensitivity and to optimize the parameters. We manually corrected the sediment transport parameters after earthquake, using the Soil and Water Assessment Tool (SWAT) model to assess the process of runoff and sediment transport in the Atsuma River basin before and after the 2018 Hokkaido Eastern Iburi Earthquake. The applicability of the SWAT model to runoff simulation in the Atsuma River basin and the changes of sediment transport process after the earthquake were studied. The research results show that the SWAT model can accurately simulate the runoff process in the Atsuma River basin, the Nash-Sutcliffe efficiency coefficient (NSE) is 0.61 in the calibration period, and is 0.74 in the verification period. The sediment transport increased greatly after the earthquake and it is roughly estimated that the amount of sediment transport per unit rainfall increased from 3.5 tons $/ \mathrm{mm} /$ year before the earthquake to 6.2 tons $/ \mathrm{mm} /$ year after the earthquake.
\end{abstract}

Keywords: SWAT model; SWAT-CUP software; runoff; sediment transport; Atsuma River basin; 2018 Hokkaido Eastern Iburi Earthquake

\section{Introduction}

Global climate change has caused natural disasters to occur frequently [1-3], Hence, it is important for human beings to adapt and respond to disasters [4]. In recent years, earthquakes have occurred frequently. From 2017 to 2019, a total of 332 earthquakes with intensity of 6 or more occurred globally, including 35 earthquakes with intensity of 7 or more and 2 earthquakes with intensity of 8 or more [5]. Earthquakes and secondary disasters associated to it have plagued humans for a long time [6,7]. The process and mechanism of gravity erosion in river basins after an earthquake are complicated, gravity erosion usually occurs randomly, and it combines with hydraulic erosion. They have a significant effect on runoff, sediment production, and sediment transport. Moreover, processes and mechanisms are also hotpots in the research fields of debris flow, soil erosion, and river sediment transport [8].

To improve the understanding of the impact of earthquakes on sediment transport processes in a river basin, the use of hydrological modeling is investigated. With the development of computer science and human understanding of various natural processes in river basins, the hydrological model has become a powerful tool for watershed research and management. The distributed hydrological model can accurately simulate various hydrological processes in river basins, and become an important tool in hydrological 
simulation research in river basins [9-11]. At the end of the last century, with the rapid development of computer technology, geographic information system (GIS), remote sensing (RS), and other innovative technologies, the development of distributed hydrological model had a solid, real-time technical platform, and the Soil and Water Assessment Tool (SWAT) model was developed in this period [12]. At present, the SWAT model is the most widely used distributed hydrological model worldwide. The SWAT model has been validated in regions of different spatial scales in the world, and is used to solve water resources management [13], rainfall-runoff analysis [14-16], watershed sediment transport process research [17,18], and other research fields [19].

Research has been conducted previously on the 2018 Hokkaido Eastern Iburi Earthquake. The research focused on earthquake-induced damage to natural slopes, the physical features and the mechanical properties of the collapsed pyroclastic fall deposits distributed in the Atsuma River basin, the complicated rupture process of earthquake, and the influence of earthquake on people [20-25]. However, there are no studies that focus on the impacts of the 2018 Hokkaido Eastern Iburi Earthquake and its secondary disasters on the Atsuma River system, and the changes in sediment transport processes in the Atsuma River basins after the earthquake. Hence, this research aims to focus on this problem.

After the 2018 Hokkaido Eastern Iburi Earthquake, a large-scale mountain collapse occurred in the Atsuma River basin, and therefore a large amount of the sediment accumulated on the slopes and along the river channels. The river environment, biological environment, ecosystems, and even the marine environment in the seas were severely impacted. This study uses the SWAT model to assess the effect of the earthquake on the sediment transport in the Atsuma River basin. The research aims to (1) study the runoff simulation accuracy of the SWAT model in the Atsuma River basin, considering the influence of reservoirs. We ran the model for a warm-up period, calibration period, and verification period; (2) analyzed the changes of sediment transport processes in the Atsuma River basin before and after the earthquake, based on high-precision runoff simulation, turbidity change characteristics, and the correlation between turbidity with sediment transport; (3) corrected the sediment transport parameters after earthquake in the Atsuma River basin, and evaluated the increase in sediment transport after the 2018 Hokkaido Eastern Iburi Earthquake, according to previous research, field investigation, and the correlation between sediment transport with turbidity.

\section{Materials and Methods}

\subsection{Atsuma River Basin}

The study area is the Atsuma River basin in southern Hokkaido. The area of the Atsuma River basin is $366.9 \mathrm{~km}^{2}$, the length of the main river channel is $52.3 \mathrm{~km}$, and the altitude of the basin is $0-600 \mathrm{~m}$ above sea level. There are two reservoirs in the Atsuma River basin which are Atsuma dam (started operation in 1970, watershed area $52 \mathrm{~km}^{2}$, effective water storage capacity $9.5 \times 10^{6} \mathrm{~m}^{3}$ ) and Apporo dam (started operation in 2017, watershed area $105.3 \mathrm{~km}^{2}$, effective water storage $4.3 \times 10^{7} \mathrm{~m}^{3}$ ). The watershed area of the Apporo dam occupies about one third of the entire Atsuma River basin, hence it can be inferred that it has a great influence on the runoff and sediment transport in the lower reaches of the Atsuma River basin. The basement complex of area where Atsuma River basin is located consists mainly of sedimentary rocks of the Neogene tertiary system: the Kawabata Formation and Fureoi Formation (alternate layers of sandstone and mudstone, sandstone, and conglomerate) and the Karumai Formation (mainly diatomaceous siltstone, sandstone, and conglomerate). At the western edge of this area, the Moebetsu Formation (diatomaceous siltstone), which is also of the Neocene tertiary system, or the sedimentary materials of the Middle Pleistocene of the Quaternary system (a sand gravel layer) forms the basement complex [21]. This area has developed an anticline/syncline structure with a north-northwest-south-southeast strike that crosses at a right angle the pressure axis from the Hidaka Mountain Range to the Yubari Mountain Range [21]. The Pacific coast, where 
the Atsuma river flows to, has abundant marine resources such as scallops and shrimp fish, and the coastal fishes. The map of the Atsuma River basin is shown in Figure 1.

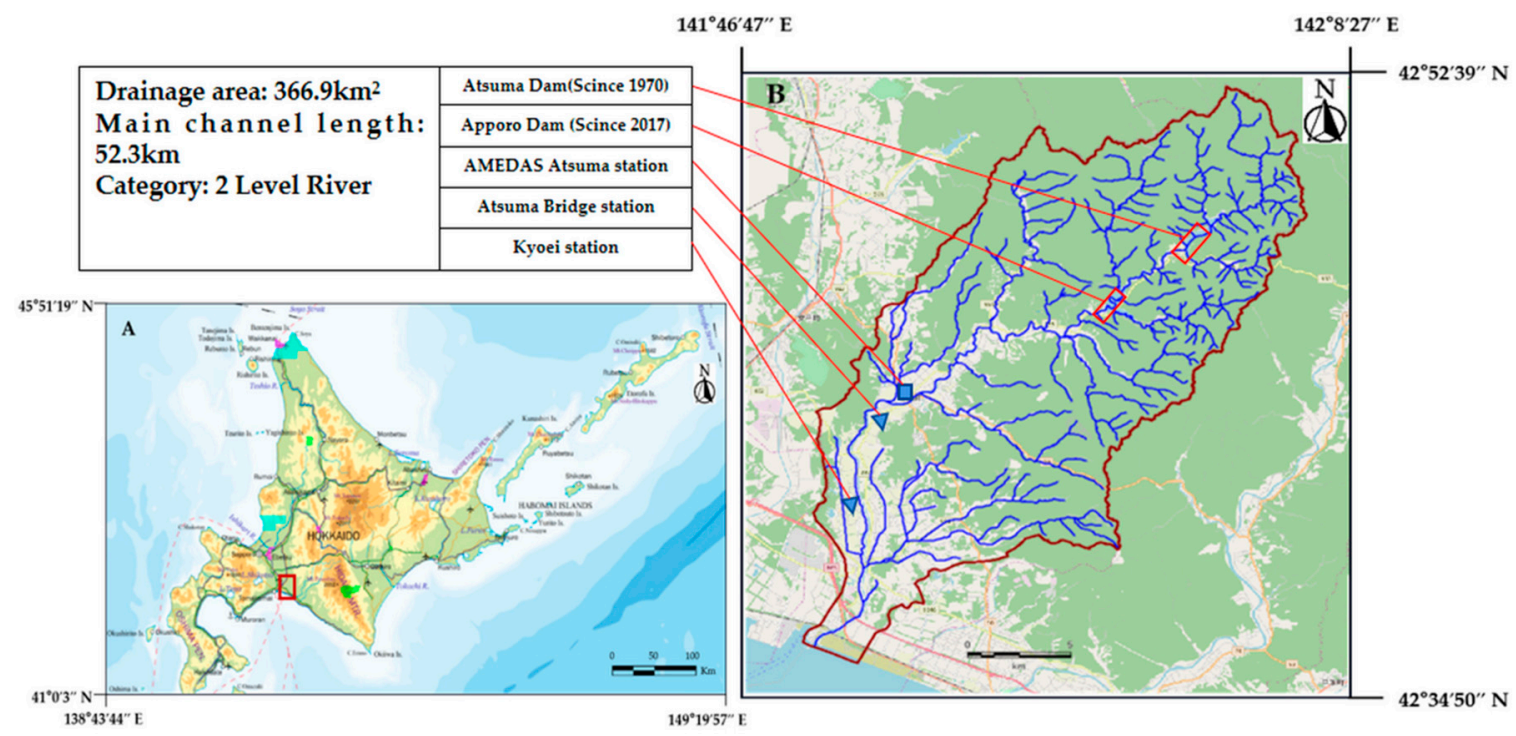

Figure 1. Map of Atsuma River basin ((A) GSI: Geospatial Information Authority of Japan (2020) [26]; (B) Open Street Map Japan (2020) [27]).

On 6 September 2018, an earthquake occurred near Atsuma, Hokkaido, Japan. The epicenter was at $42.7^{\circ} \mathrm{N}, 142^{\circ} \mathrm{E}$, depth was $37.0 \mathrm{~km}$ [22]. Tremors were felt in most of Hokkaido. The Japan Meteorological Agency recorded a maximum intensity of 7 in the eastern parts of the Hokkaido Iburi region. This was the first time for an earthquake with an intensity of 7 or more to be recorded in Hokkaido. The basement rock around the epicenter mainly consists of Neogene sedimentary rocks that are conglomerate, sandstone, and mudstone of Fureoi formation of Middle to Late Miocene, sandstone, hard shale, and mudstone of Karumai formation of Late Miocene, and conglomerate, sandstone, hard shale, and siltstone of Moebetsu (Nina) formation of Late Miocene to Early Pliocene [28].

Uplift of up to $\approx 7 \mathrm{~cm}$ is predominantly distributed in the source region, and eastward movement of up to $\approx 4 \mathrm{~cm}$ is widely observed on the eastern side of the source region. The fault plane extends in a north-south direction and is dipping to the east with a dip angle of $74^{\circ}$ and the fault top is positioned at around $15 \mathrm{~km}$ in depth. There were 459 earthquakes that occurred between 6 September 2018 03:00 and 7 September 2018 23:59, the aftershock area extended $25 \mathrm{~km}$ horizontally, approximately in the N-S direction, and that $95 \%$ of the hypocenters were distributed at depths from 20 to $40 \mathrm{~km}$ [29].

The 2018 Hokkaido Eastern Iburi Earthquake caused a large number of shallow landslides, and several large-scale deep-seated landslides involving basement rocks such as shale and mudstone of Miocene, these landslides occurred over approximately $400 \mathrm{~km}^{2}$ hilly areas $200-400 \mathrm{~m}$ in elevation. The total landslides area is $43.8 \mathrm{~km}^{2}$ which includes $33.1 \mathrm{~km}^{2}$ in the Atsuma River basin; the total accumulation area is $11.8 \mathrm{~km}^{2}$ which includes $9.6 \mathrm{~km}^{2}$ in the Atsuma River basin, and the total volume of landslides is 30 million $\mathrm{m}^{3}$ [21]. After 2018 Hokkaido Eastern Iburi Earthquake and large-scale landslides, within the Atsuma River basin, the safety factors under natural condition are all large indicating that no slopes would slide with no rainfall [30].

An example of the landslides that occurred due to the 2018 Hokkaido Eastern Iburi Earthquake in the Atsuma River basin is shown in Figure 2. About 4500 landslides occurred after earthquake in the Atsuma River basin, and large quantities of sediment and woody debris were deposited in river channels and plains. The distribution of slope collapse/sediment accumulations in the Atsuma River basin caused by the earthquake is shown in Figure 3. The slope degree map of the Atsuma River basin is shown in Figure 4. 


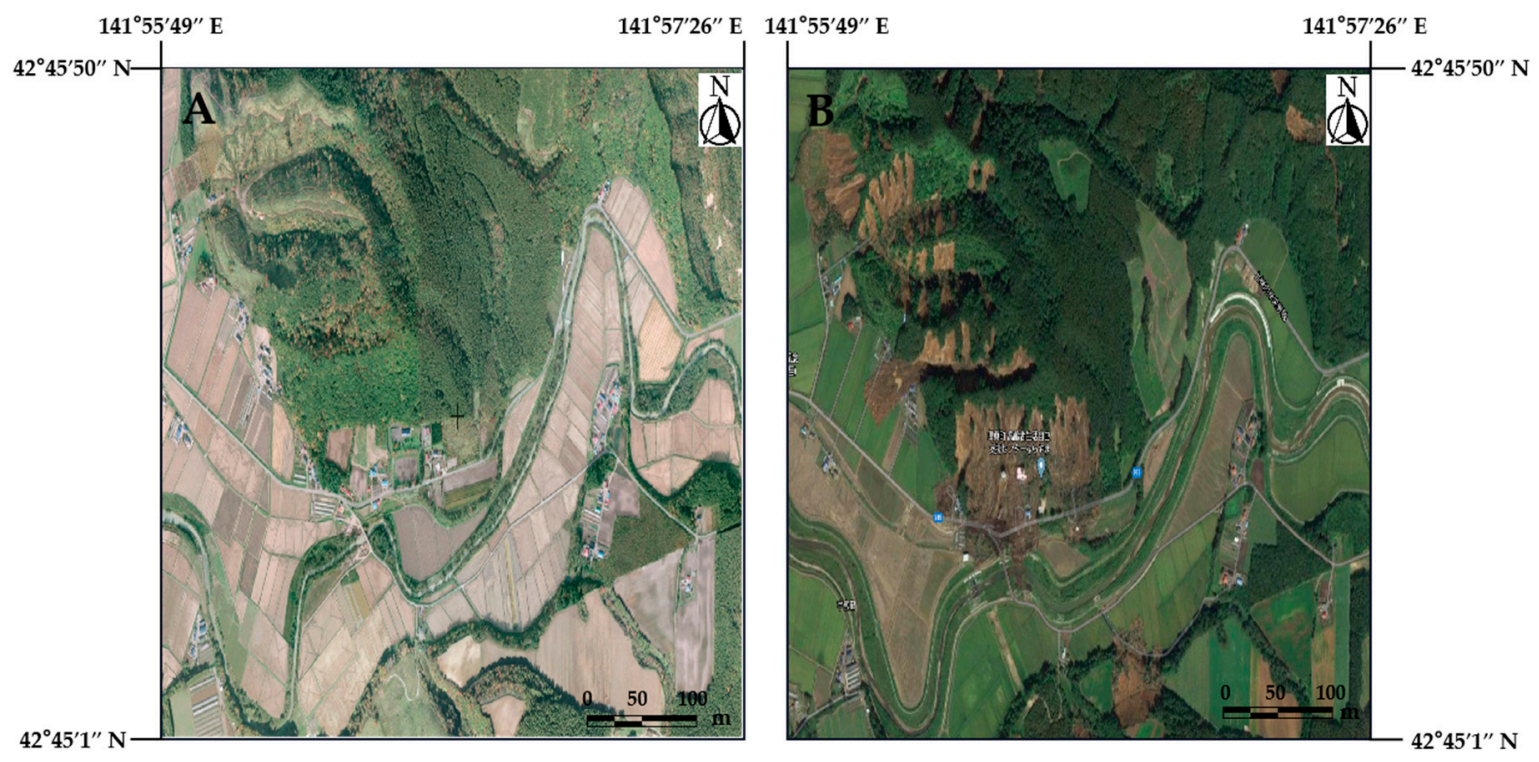

Figure 2. Landslide caused by the 2018 Hokkaido Eastern Iburi Earthquake in the Atsuma River basin ((A) GSI: Geospatial Information Authority of Japan (2017) [26]; (B) Google Earth (2020) [31]).

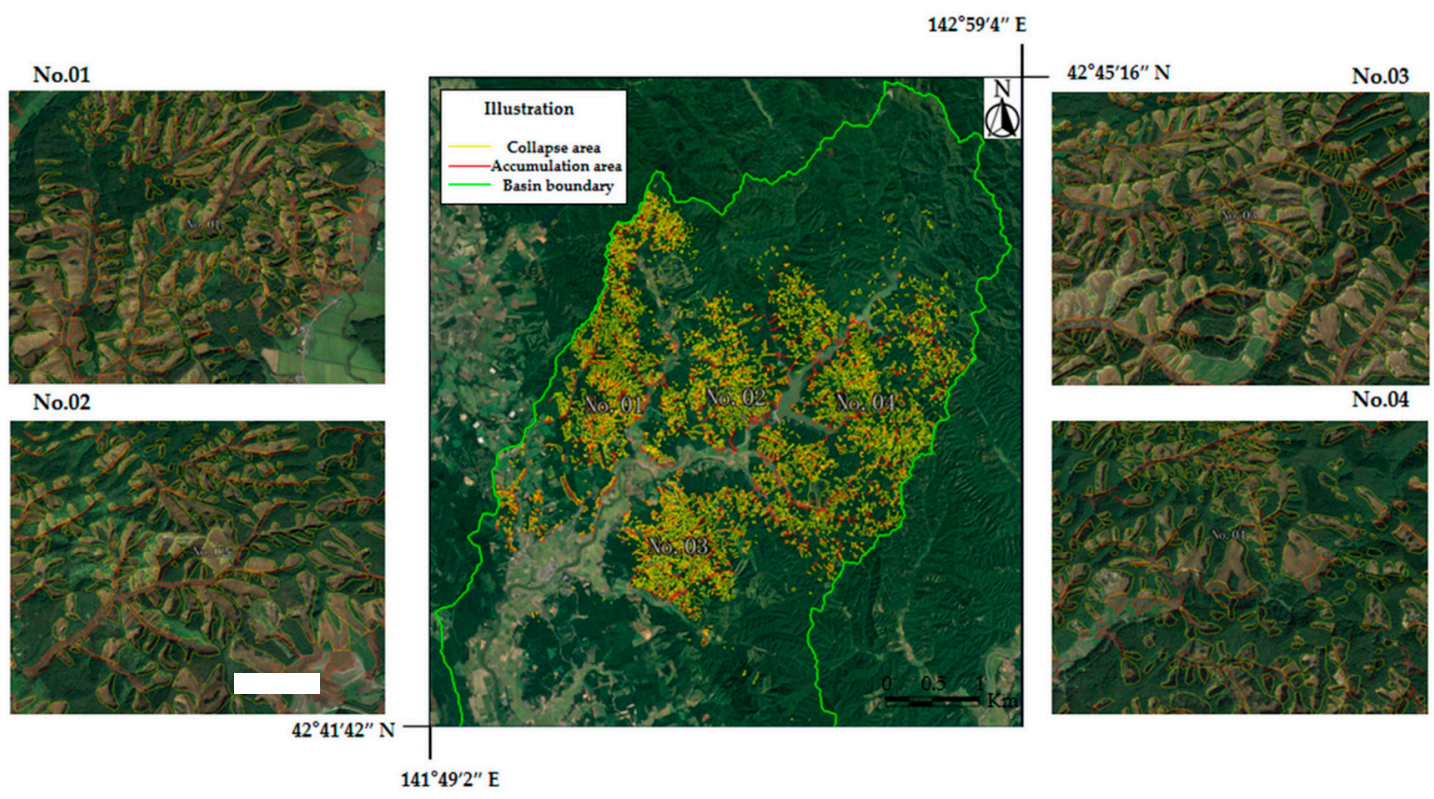

Figure 3. Distribution map of slope collapse/sediment accumulation in the Atsuma River basin caused by the 2018 Hokkaido Eastern Iburi Earthquake [31].

\subsection{SWAT Model}

Currently, the Soil and Water Assessment Tool (SWAT) is the most widely used distributed hydrological model worldwide. It was developed by the US Department of Agriculture-Agricultural Research Service (USDA-ARS) [18]. The SWAT model is a river basin, or watershed scale model developed to predict the impact of land management practices on water, sediment, and agricultural chemical yields in river basins over long periods of time. 


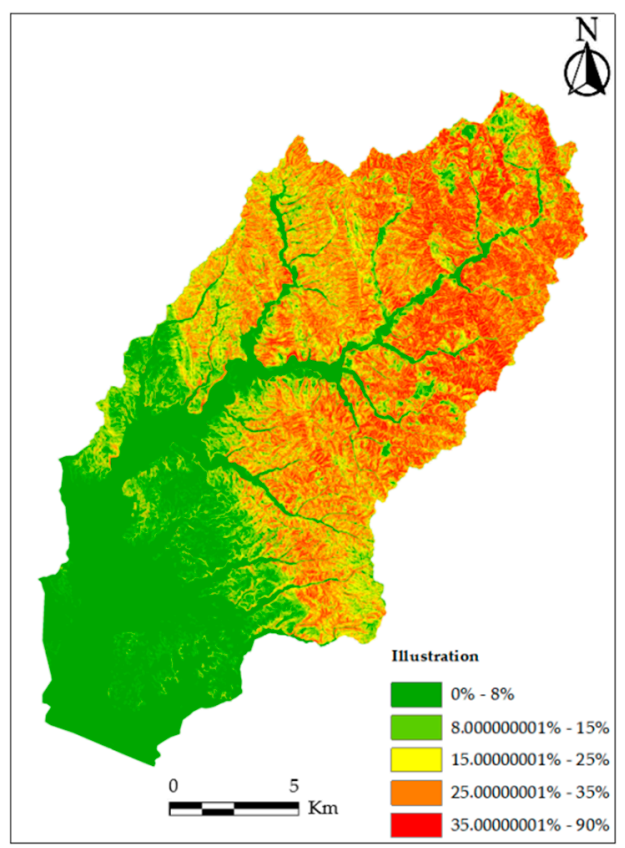

Figure 4. The slope degree map of the Atsuma River basin.

\subsubsection{Modules and Feature of SWAT Model}

The main modules of SWAT model are referring to meteorology, soil, hydrology, plant growth, nutrients, pollutants, management measures. The river basin is first divided into several sub-basins with basically the same climatic conditions, and then every subbasin is divided into Hydrological Response Units (HRUs) with the same land type, soil conditions, terrain, and management methods. In each HRU the number of research factors is calculated separately, and the total amount is calculated finally by confluence calculation. By dividing sub-basins and HRUs, researchers can analyze the spatial characteristics of watershed hydrological processes. The process of runoff, and migration of sediment, nutrients, and pollutants can be simulated by SWAT to reflect the real water cycle process in a river basin. Furthermore, the water cycle process follows the principle of water balance. The Equation (1) used by SWAT model is as following:

$$
\mathrm{SW}_{\mathrm{t}}=\mathrm{SW}_{\mathrm{o}}+\mathrm{t} \sum_{\mathrm{i}=1}\left(\mathrm{R}_{\text {day }}-\mathrm{Q}_{\text {surf }}-\mathrm{E}_{\mathrm{a}}-\mathrm{W}_{\text {seep }}-\mathrm{Q}_{\mathrm{gw}}\right)
$$

where $\mathrm{SW}_{\mathrm{t}}$ is final soil moisture content $(\mathrm{mm}), \mathrm{SW}_{\mathrm{o}}$ is initial water content $(\mathrm{mm}), \mathrm{t}$ is time in days, $R_{\text {day }}$ is precipitation $(\mathrm{mm}), Q_{\text {surf }}$ is surface runoff $(\mathrm{mm}), E_{a}$ is Evapotranspiration $(\mathrm{mm}), \mathrm{W}_{\text {seep }}$ is amount of water seeping into the soil profile $(\mathrm{mm})$, and $\mathrm{Q}_{\mathrm{gw}}$ is amount of return flow $(\mathrm{mm})$.

The SWAT model uses the Modified Universal Soil Loss Equation (MUSLE) to model changes in erosion and sediment transport. MUSLE used the amount of runoff to simulate erosion and estimate sediment yields. The Equation (2) is defined as the following:

$$
\text { Sed }=11.8 \times\left(\mathrm{Q}_{\text {surf }} \times \mathrm{q}_{\text {peak }} \times \text { area }_{\text {hru }}\right)^{0.56} \times \mathrm{K} \times \mathrm{C} \times \mathrm{P} \times \mathrm{LS} \times \mathrm{CFRG}
$$

where Sed is the sediment yield (tons/day) of a HRU, $\mathrm{Q}_{\text {surf }}$ is the volume of surface runoff $\left(\mathrm{mm} / 10^{3} \cdot \mathrm{m}^{2}\right), \mathrm{q}_{\text {peak }}$ is the peak runoff rate $\left(\mathrm{m}^{3} / \mathrm{s}\right)$, area hru is the area of the HRU $\left(10^{3} \cdot \mathrm{m}^{2}\right)$, $\mathrm{K}$ is the Universal Soil Loss Equation (USLE) soil erodibility factor (dimensionless), $\mathrm{C}$ is the USLE cover and management factor (dimensionless), $\mathrm{P}$ is the USLE support practice factor (dimensionless), LS is the USLE topographic factor (dimensionless), and CFRG is the coarse fragment factor (dimensionless). 


\subsubsection{Basic Data of SWAT Model}

The SWAT model inputs are a digital elevation model (DEM), land use data, soil data, and weather data, which are shown in Table 1. All geographic data need to be projected from geographic coordinate system (WGS84) to metric coordinate system (JGD2000/Japan Plane Rectangular CSII). SWAT is a watershed modeling package that can be used as an extension within Geographic Information System (GIS) interface, the QGIS interface of the SWAT2009 version was used to discretize a watershed and extract the SWAT model input files.

Table 1. The SWAT model input data for the Atsuma River basin.

\begin{tabular}{|c|c|c|c|}
\hline Data Type & Description & Resolution & Source \\
\hline Topography map & Digital elevation model (DEM) & $10 \mathrm{~m}$ & $\begin{array}{l}\text { Geographical information Authority of } \\
\text { Japan }\end{array}$ \\
\hline Land use map & Land use classifications & $100 \mathrm{~m}$ & $\begin{array}{l}\text { Ministry of Land, Infrastructure, } \\
\text { transport and Tourism of Japan }\end{array}$ \\
\hline Soils map & Soil types & $1 / 200,000$ & $\begin{array}{l}\text { Ministry of Land, Infrastructure, } \\
\text { Transport and Tourism of Japan }\end{array}$ \\
\hline \multirow{4}{*}{ Weather } & Precipitation & 450 stations & $\begin{array}{l}\text { Japan Meteorological Business Support } \\
\text { Center }\end{array}$ \\
\hline & Minimum and maximum temperature & Atsuma station & \multirow{3}{*}{ Japan Meteorological Agency } \\
\hline & Solar radiation & Sapporo station & \\
\hline & Relative humidity & Tomakomai station & \\
\hline
\end{tabular}

The DEM was used to delineate the catchment and provide topographic parameters. The catchment area of the Atsuma River basin was delineated and discretized into 65 sub-basins using the $10 \mathrm{~m}$ mesh digital elevation model of Geographical Information Authority of Japan. The land use subdivision mesh data in 2014 of Ministry of Land, Infrastructure, Transport and Tourism was used as land use data to estimate vegetation and their parameters were input to the model. The 1/200,000 Land Classification Basic Survey of Ministry of Land, Infrastructure, Transport and Tourism was used as soil data in this study. The land use data and the soil data were overlaid to derive 225 unique HRUs. The DEM, land use, and soil conditions in the Atsuma River basin are shown in Figure 5.

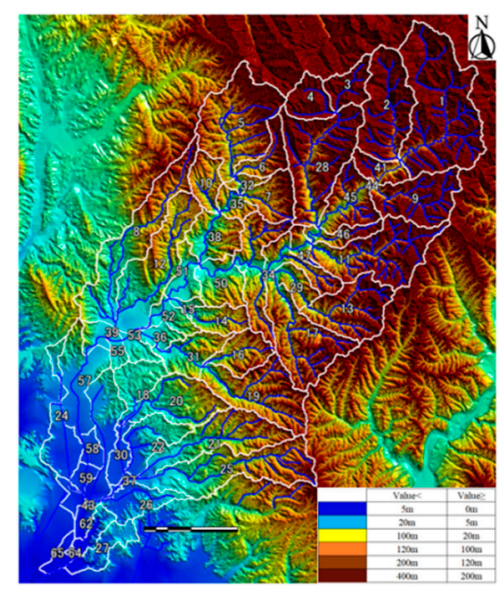

(A)

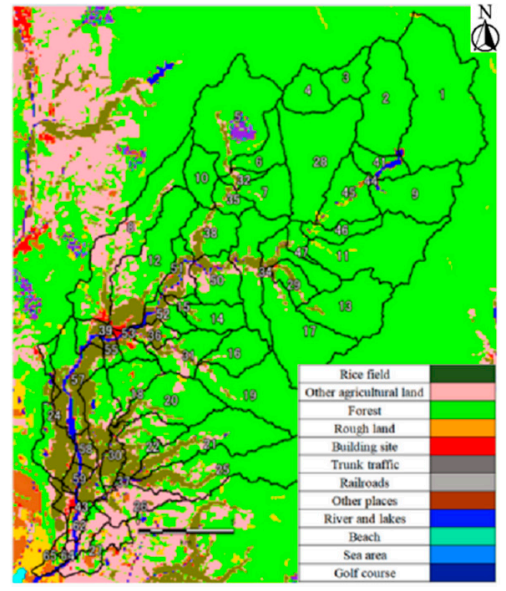

(B)

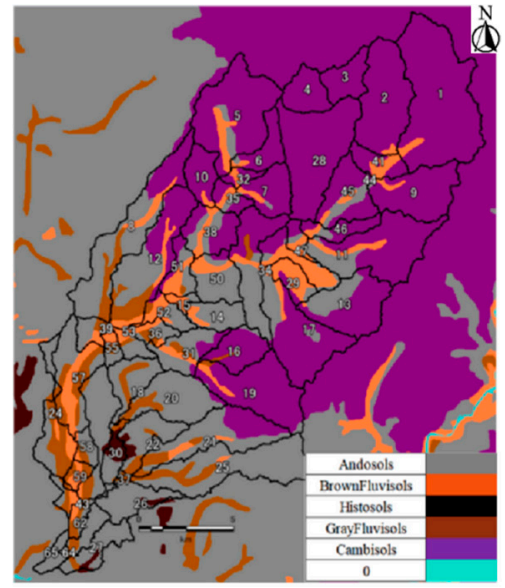

(C)

Figure 5. The elevation (A), land use (B), and soil (C) conditions in Atsuma River basin.

Daily precipitation at 450 radar precipitation stations in the Atsuma River basin were used to run the model. The minimum and maximum temperature data, average wind 
speed data at Atsuma station were used, the relative humidity data at Tomakomai station was used, the solar radiation data at Sapporo station was used.

The turbidity data is based on the observation data at Kyoei Station which are from 14 April 2018 to December 2019. However, there were four periods of time when data was not collected. The observation discharge data at Atsuma Bridge station was collected from 2015 to 2019, but there was a period when no data was collected from 20 July 2017 to 30 September 2017. The outflow data at the Atsuma dam is from 1 January 2015 to 5 September 2018, but there was a period where no data was collected after 2017. The inflow and outflow data at Apporo dam was from 10 August 2018 to 10 November 2018, and from 20 March 2019 to 25 June 2019.

\subsubsection{Parameters of SWAT Model}

The SWAT model itself had the function of generating default parameters according to the soil data, land use data, and elevation data of the study area. Researchers could also adjust the parameters by historical hydrological data or the SWAT-CUP software. This study uses the SWAT-CUP software to analyze the runoff parameter sensitivity and to modify parameters accordingly. Firstly, sensitivity analysis was performed to identify the most sensitive runoff parameters for the model calibration using the Global Sensitivity part of SWAT-CUP. Determining the most sensitive parameters for reproducing runoff were Snow pack temperature lag factor (TIMP), Curve number (CN2), Melt factor for snow on 21 December (SMFMN), Melt factor for snow on 21 June (SMFMX), Temperature lapse rate (TLAPS), Available water capacity (SOL_AWC), Snow melt base temperature (SMTMP), Effective hydraulic conductivity in main and tributary channel alluvium (CH_K2, CH_K1), Minimum snow water content that corresponds to 100\% snow (SNOCOVMX), Manning' " $n$ " value for the main and tributary channel (CH_N2, CH_N1), Soil evaporation compensation factor (ESCO), Precipitation lapse rate (PLAPS), and Snowfall temperature (SFTMP). Next, the sensitive runoff parameters were automatically calibrated using the Sequential Uncertainty Fitting (SUFI-2) algorithm, and the corrected runoff parameters were obtained. Regarding sediment parameters, because this study does not have measured sediment transport data, SWAT-CUP cannot be used for sensitivity analysis and correction of sediment parameters. According to previous research, field investigation, the correlation between sediment transport with turbidity and multiple simulation attempts, the sediment transport parameters after earthquake were chosen and corrected manually. The SWAT model was run daily for 11 years, the warm up period is from 2009 to 2014, the period from 2015 to 2017 was used for the calibration and the period from 2018 to 2019 was used for the validation. Table 2 shows the parameters in the Atsuma River basin.

Table 2. SWAT parameters in the Atsuma River basin.

\begin{tabular}{|c|c|c|c|c|c|}
\hline Variable & Parameter Name & $\begin{array}{l}\text { Order of } \\
\text { Sensitivity }\end{array}$ & Description & $\begin{array}{l}\text { Default } \\
\text { Values }\end{array}$ & $\begin{array}{l}\text { Corrected } \\
\text { Values }\end{array}$ \\
\hline \multirow{9}{*}{ Runoff } & v_TIMP.bsn * & 1 & Snow pack temperature lag factor & 1 & 0.22 \\
\hline & r_CN2.mgt ${ }^{* * *}$ & 2 & $\begin{array}{l}\text { Initial SCS runoff curve number for } \\
\text { moisture condition II }\end{array}$ & 73 & 60 \\
\hline & v_SMFMN.bsn ** & 3 & $\begin{array}{l}\text { Melt factor for snow on } 21 \text { December } \\
\left(\mathrm{mm} \mathrm{H}_{2} \mathrm{O} /{ }^{\circ} \mathrm{C} \text {-day }\right)\end{array}$ & 4.5 & 3.17 \\
\hline & v_SMFMX.bsn & 4 & $\begin{array}{l}\text { Melt factor for snow on } 21 \text { June } \\
\left(\mathrm{mm} \mathrm{H} \mathrm{H}_{2} \mathrm{O} /{ }^{\circ} \mathrm{C} \text {-day }\right)\end{array}$ & 4.5 & 10 \\
\hline & v_TLAPS.sub & 5 & Temperature lapse rate $\left({ }^{\circ} \mathrm{C} / \mathrm{km}\right)$ & 0 & -6 \\
\hline & v_SOL_AWC.sol & 6 & $\begin{array}{l}\text { Available water capacity of the soil layer } \\
\qquad\left(\mathrm{mm} \mathrm{H}_{2} \mathrm{O} / \mathrm{mm} \text { soil }\right)\end{array}$ & 0.143 & 0.0003 \\
\hline & v_SMTMP.bsn & 7 & Snow melt base temperature $\left({ }^{\circ} \mathrm{C}\right)$ & 0.5 & -0.83 \\
\hline & v_CH_K2.rte & 8 & $\begin{array}{l}\text { Effective hydraulic conductivity in } \\
\text { tributary channel alluvium (mm/hrh) }\end{array}$ & 0 & 4.58 \\
\hline & v_CH_K1.sub & 9 & $\begin{array}{l}\text { Effective hydraulic conductivity in } \\
\text { tributary channel alluvium }(\mathrm{mm} / \mathrm{h})\end{array}$ & 0 & 19.65 \\
\hline
\end{tabular}


Table 2. Cont.

\begin{tabular}{|c|c|c|c|c|c|}
\hline Variable & Parameter Name & $\begin{array}{c}\text { Order of } \\
\text { Sensitivity }\end{array}$ & Description & $\begin{array}{l}\text { Default } \\
\text { Values }\end{array}$ & $\begin{array}{l}\text { Corrected } \\
\text { Values }\end{array}$ \\
\hline \multirow{6}{*}{ Runoff } & v_SNOCOVMX.bsn & 10 & $\begin{array}{l}\text { Minimum snow water content that } \\
\text { corresponds to } 100 \% \text { snowcover, SNO100, } \\
\qquad\left(\mathrm{mm} \mathrm{H}_{2} \mathrm{O}\right)\end{array}$ & 1 & 0.05 \\
\hline & v_CH_N2.rte & 11 & Manning's " $n$ " value for the main channel & 0.014 & 0.07 \\
\hline & v_CH_N1.sub & 12 & Manning's " $\mathrm{n}$ " value for the main channel & 0.014 & 0.12 \\
\hline & v_ESCO.bsn & 13 & Soil evaporation compensation factor & 0.95 & 0.85 \\
\hline & v_PLAPS.bsn & 14 & Precipitation lapse rate $\left(\mathrm{mm} \mathrm{H}_{2} \mathrm{O} / \mathrm{km}\right)$ & 0 & 200 \\
\hline & v_SFTMP.bsn & 15 & Snowfall temperature $\left({ }^{\circ} \mathrm{C}\right)$ & 1 & -2.93 \\
\hline Variable & \multicolumn{2}{|c|}{ Parameter Name } & Description & $\begin{array}{c}\text { Before } \\
\text { Earthquake }\end{array}$ & $\begin{array}{c}\text { After } \\
\text { Earthquake }\end{array}$ \\
\hline \multirow{5}{*}{ Sediment } & \multicolumn{2}{|c|}{ v_CH_COV.rte } & Channel cover factor & 0 & 0.8 \\
\hline & \multicolumn{2}{|c|}{ v_SPCON.bsn } & $\begin{array}{c}\text { Linear re-entrained parameter for channel } \\
\text { sediment routing }\end{array}$ & 0.0001 & 0.01 \\
\hline & \multicolumn{2}{|c|}{ v_SPEXP.bsn } & $\begin{array}{l}\text { Exponent of re-entrained parameter for } \\
\text { channel sediment routing }\end{array}$ & 1 & 1.5 \\
\hline & \multirow{2}{*}{\multicolumn{2}{|c|}{$\begin{array}{l}\text { v_CH_EROD.rte } \\
\text { v_USLE_K.sol }\end{array}$}} & Channel erodibility & 0 & 0.5 \\
\hline & & & USLE soil erodibility factor & 0.265 & 0.65 \\
\hline
\end{tabular}

* The extension (e.g., mgt) refers to the SWAT input file where the parameter occurs. ${ }^{* *}$ The qualifier (v) refers to the substitution of a parameter by a value from the given range. ${ }^{* * *}$ The qualifier $(r)$ refers to relative change in the parameter where the value from the SWAT database is multiplied by 1 plus a factor in the given range.

\subsubsection{Performing Calculation}

The collected data was applied to set up the model, then the SWAT model was configured and parameters were set. The SWAT analysis was conducted in the simulation window. The simulation manager could perform calculation by combining the rainfall data, parameters, and other setups. After the calculation, the SWAT model could display the calculation results at any HRUs or sub-basins in the river basin.

\subsection{Methodology}

\subsubsection{Research Methods}

In this research, the changes of sediment transport process in the Atsuma River basin before and after the 2018 Hokkaido Eastern Iburi Earthquake were studied by the following procedure.

- Considering the influence of reservoirs, the warm-up period was set from 2009 to 2014, calibration period from 2015 to 2017. We used the SWAT-CUP software to analyze the runoff parameter sensitivity and to optimize the parameters. Furthermore, the corrected parameters were used to reproduce the runoff process from 2018 to 2019 by SWAT model. The applicability and accuracy of the SWAT model to runoff simulation in the Atsuma River basin was verified.

- The sediment transport process from 2018 to 2019 was reproduced supposing that no earthquake occurred in 2018. Then, the changes in turbidity were analyzed before and after the earthquake, the correlation and relationship changes between sediment transport and turbidity before and after the earthquake were studied, and it was proved that the sediment transport process has been changed after the 2018 Hokkaido Eastern Ibur Earthquake.

- According to previous research, field investigation and the correlation between sediment transport and turbidity, the sediment transport parameters after the earthquake were corrected. Furthermore, using the corrected parameters the increase in sediment transport was evaluated after 2018 Hokkaido Eastern Iburi Earthquake. 


\subsubsection{Error Analysis}

Model evaluation is an important measure to verify the accuracy of the model. In this study, the advantages and disadvantages of SWAT model fitness adopt three model evaluation methods, including determination coefficient $\left(R^{2}\right)$ [32], Nash-Sutcliffe efficiency coefficient (NSE) [33], and percent bias (PBIAS) [34]. The calculation process formula of $\mathrm{R}^{2}$, NSE, and PBIAS are shown in Equations (3)-(5):

$$
\begin{gathered}
\mathrm{R}^{2}=\frac{\sum_{\mathrm{i}=1}^{\mathrm{T}}\left(\mathrm{O}_{\mathrm{i}}-\overline{\mathrm{O}}\right)\left(\mathrm{S}_{\mathrm{i}}-\overline{\mathrm{S}}\right)}{\sqrt{\sum_{\mathrm{i}=1}^{\mathrm{T}}\left(\mathrm{O}_{\mathrm{i}}-\overline{\mathrm{O}}\right)^{2} \sum_{\mathrm{i}=1}^{\mathrm{T}}\left(\mathrm{S}_{\mathrm{i}}-\overline{\mathrm{S}}\right)^{2}}} \\
\mathrm{NSE}=1-\frac{\sum_{\mathrm{i}=1}^{\mathrm{T}}\left(\mathrm{O}_{\mathrm{i}}-\mathrm{S}_{\mathrm{i}}\right)^{2}}{\sum_{\mathrm{i}=1}^{\mathrm{T}}\left(\mathrm{O}_{\mathrm{i}}-\overline{\mathrm{O}}\right)^{2}} \\
\text { PBTAS }=\left[\frac{\sum_{\mathrm{i}=1}^{\mathrm{T}}\left(\mathrm{O}_{\mathrm{i}}-\mathrm{S}_{\mathrm{i}}\right)}{\sum_{\mathrm{i}=1}^{\mathrm{T}} \mathrm{O}_{\mathrm{i}}}\right]
\end{gathered}
$$

where, $\mathrm{T}$ is the calculation time (days); $\mathrm{O}_{\mathrm{i}}$ is the observation flow at time $\mathrm{i} ; \mathrm{S}_{\mathrm{i}}$ is the calculation flow at time $\mathrm{i} ; \overline{\mathrm{O}}$ is the observation average flow; $\overline{\mathrm{S}}$ is the calculation average flow.

Combined with previous experience, in this study, model simulation was judged as satisfactory if NSE $>0.6, R^{2}>0.7$ and PBIAS $= \pm 25 \%$ for flow $[31,32]$.

\section{Results}

\subsection{Discharge}

In this study, the most sensitive parameters for reproducing runoff were Snow pack temperature lag factor (TIMP), Curve number (CN2), Melt factor for snow on 21 December (SMFMN), Melt factor for snow on 21 June (SMFMX), Temperature lapse rate (TLAPS), Available water capacity (SOL_AWC), Snow melt base temperature (SMTMP), Effective hydraulic conductivity in main and tributary channel alluvium $\left(\mathrm{CH} \_\mathrm{K} 2, \mathrm{CH} \_\mathrm{K} 1\right)$, Minimum snow water content that corresponds to $100 \%$ snow (SNOCOVMX), Manning's " $n$ " value for the main and tributary channel (CH_N2, CH_N1), Soil evaporation compensation factor (ESCO), Precipitation lapse rate (PLAPS), and Snowfall temperature (SFTMP). These runoff parameters were adjusted from the SWAT initial estimates by SWAT-CUP software to fit the model simulations with the observation discharge. Since the simulation results after the earthquake are better than before the earthquake, and the GW_Delay, CH_K1, $\mathrm{CH}$ _K2 parameters are big, it can be inferred that after the earthquake, the aquifer recharge runoff increased in the Atsuma River basin, and the effect of the aquifer delaying rainfall directly into the river was enhanced. The collapsed soil accumulated in the river channel due to the earthquake may temporarily store rainfall and river water.

The results are shown in Figure 6. The error analysis results are shown in Table 3. It can be observed that, during the calibration period, the $\mathrm{R}^{2}$ is 0.69 , the NSE is 0.61 , and the PBIAS is $17.3 \%$, and in the verification period, the $R^{2}$ is 0.77 , the NSE is 0.74 , and the PBIAS is $-8 \%$. The error of the runoff simulation is small, and the simulation effect is good. Hence, the overall simulation accuracy is very high, and it proves that the SWAT model can simulate the runoff process in the Atsuma River basin with high accuracy. The missing observation discharge data from 20 July 2017 to 30 September 2017 is an important reason that the accuracy decreased during the calibration period. Water volume budget is the foundation of water cycle in river basin. As the carrier and source of energy for sediment transport, the runoff has a huge impact on sediment transport. The ratio of 
annual precipitation to the total amount of sediment transport is an important indicator that reflects the situation of sediment transport. Table 4 shows the water volume budget upstream Atsuma Bridge station in the Atsuma River basin. Through analyses, it can be found that from 2015 to 2019, the proportion of precipitation transform into runoff has increased. Comparing the precipitation in 2019 with that of 2015-2018, it can be observed that the precipitation in 2019 is the lowest in the past five years. Comparing the runoff, it can be observed that the runoff in 2019 is relatively less, and it is significantly lower than the runoff in 2018. Regarding the precipitation before the earthquake, there were five major precipitation events from April 2018 to the earthquake. The nearest precipitation event to the earthquake occurred on 13-18 August 2018, 18 days before the earthquake. These situations need to be fully considered when studying the process of sediment transport.

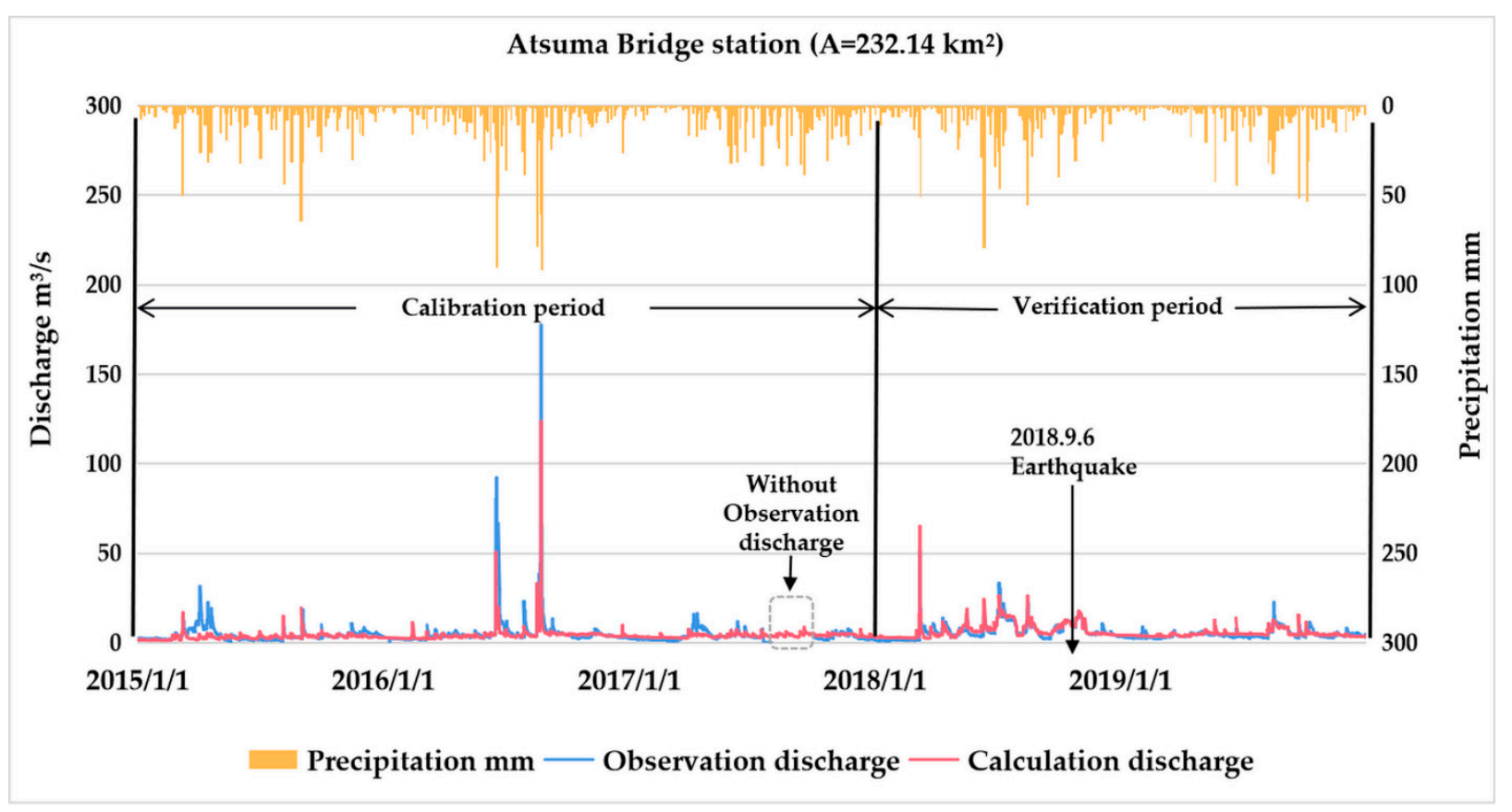

Figure 6. The comparison of observation discharge and calculation discharge at Atsuma Bridge station from 2015 to 2019 (note: observation discharge data is missing from 20 July to 30 September 2017, not included).

Table 3. Error analysis of SWAT in runoff simulation.

\begin{tabular}{cccc}
\hline Atsuma Bridge Station & $\mathbf{R}^{\mathbf{2}}$ & NSE & PBIAS \\
\hline Calibration period & 0.69 & 0.61 & $17.3 \%$ \\
Verification period & 0.77 & 0.74 & $-8 \%$ \\
\hline
\end{tabular}

Table 4. Water volume budget upstream Atsuma Bridge station.

\begin{tabular}{ccccccc}
\hline Year & $\mathbf{2 0 1 5}\left(\mathbf{m}^{3} / \mathbf{a}\right)$ & $\mathbf{2 0 1 6}\left(\mathbf{m}^{\mathbf{3}} / \mathbf{a}\right)$ & $\mathbf{2 0 1 7}\left(\mathbf{m}^{\mathbf{3}} / \mathbf{a}\right)$ & $\mathbf{2 0 1 8}\left(\mathbf{m}^{\mathbf{3}} / \mathbf{a}\right)$ & $\mathbf{2 0 1 9}\left(\mathbf{m}^{\mathbf{3}} / \mathbf{a}\right)$ & Average $\left(\mathbf{m}^{3} / \mathbf{a}\right)$ \\
\hline Precipitation & $2.96 \times 10^{8}$ & $3.57 \times 10^{8}$ & $2.74 \times 10^{8}$ & $3.37 \times 10^{8}$ & $2.52 \times 10^{8}$ & $3.03 \times 10^{8}$ \\
Rainfall & $2.31 \times 10^{8}$ & $3.01 \times 10^{8}$ & $2.5 \times 10^{8}$ & $2.91 \times 10^{8}$ & $2.36 \times 10^{8}$ & $2.63 \times 10^{8}$ \\
Snowfall & $6.49 \times 10^{7}$ & $4.72 \times 10^{7}$ & $2.43 \times 10^{7}$ & $4.6 \times 10^{7}$ & $1.6 \times 10^{7}$ & $4.0 \times 10^{7}$ \\
Runoff & $1.36 \times 10^{8}$ & $1.93 \times 10^{8}$ & $9.5 \times 10^{7}$ & $2.14 \times 10^{8}$ & $1.78 \times 10^{8}$ & $1.63 \times 10^{8}$ \\
\hline
\end{tabular}

\subsection{Sediment Transport}

The turbidity and suspended sediment concentration (SSC) are correlated [35-40], and turbidity can be used as a surrogate for suspended sediment concentration (SSC) [41]. Since the observed sediment transport data in the Atsuma River basin is absent, the change 
of sediment transport can be judged by analyzing the relationship and correlation between turbidity and sediment transport.

In this study, the sediment transport means the load of suspended sediment $(\mathrm{g} / \mathrm{s})$, which is equal to the total suspended sediments $(\mathrm{mg} / \mathrm{L})$ multiplied by observation discharge $\left(\mathrm{m}^{3} / \mathrm{s}\right)$. It can be observed from Figure 7 that the peak time of turbidity and sediment transport are close. Hence, it is once again proven that turbidity and sediment transport are strongly correlated.

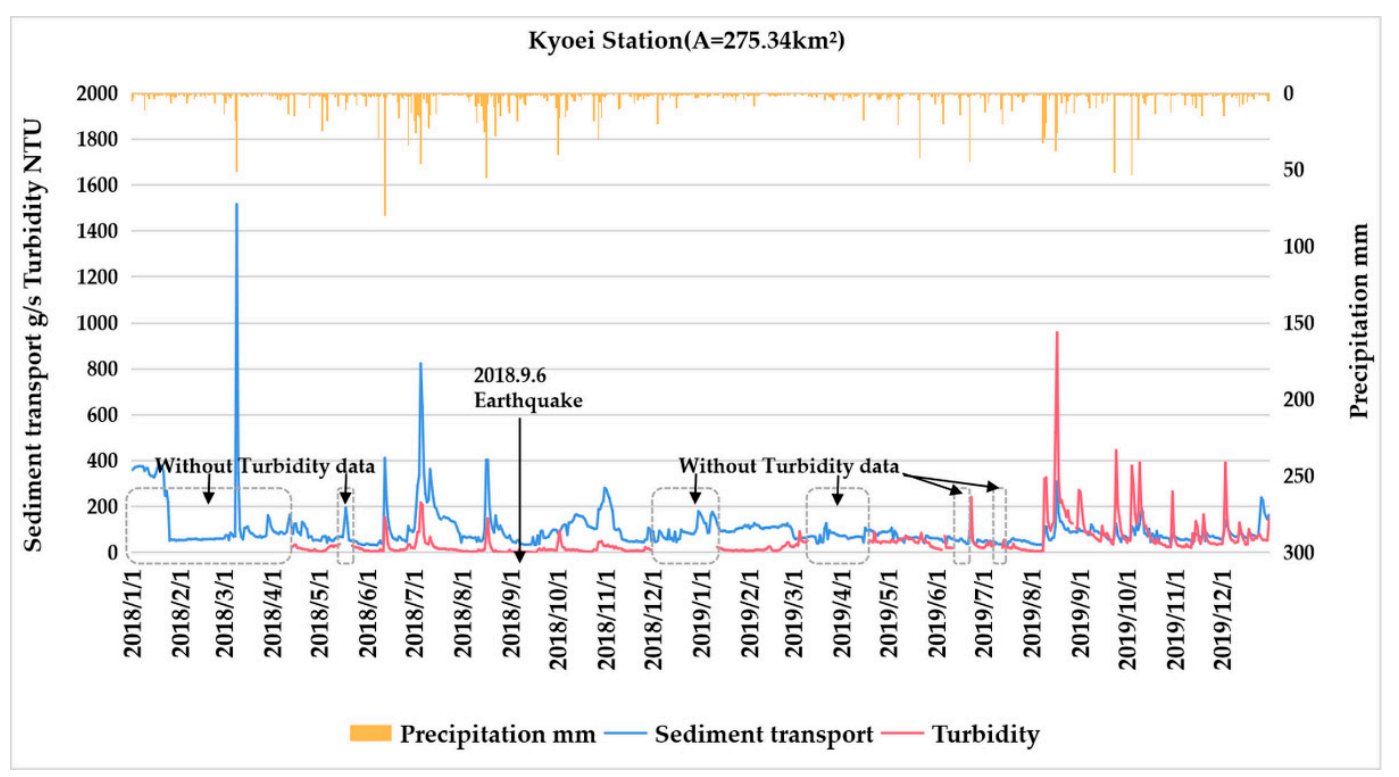

Figure 7. Comparison of turbidity and sediment transport at Kyoei station.

The changes in turbidity data have great reference significance for judging the changes in sediment transport. Analyzing Figure 7, it can be observed that compared to the turbidity in 2018, the turbidity increased significantly in 2019. Although, after the 2018 Hokkaido Eastern Iburi Earthquake, there was no significant increase of turbidity at once. However, since August 2019, turbidity has increased significantly. This is because the Apporo dam has returned to normal, the water level of Atsuma River basin has risen, and the sediment flowing into the river due to the 2018 Hokkaido Eastern Iburi Earthquake has flowed downstream. The increased turbidity is a favorable evidence for the increase in sediment transport in 2019.

There is a relationship between the increased turbidity and rainfall. In 2018 and previously, even during heavy rain with an hourly rainfall of $10 \mathrm{~mm} / \mathrm{h}$, the turbidity increased approximately to 500 NTU in the Atsuma River basin, but in 2019, the maximum turbidity increased approximately to 1000 NTU. Hence, it can be proved that the value of turbidity in 2019 is greater, and correspondingly, the sediment transport increased after the 2018 Hokkaido Eastern Iburi Earthquake.

Analyzing the changes in the calculation sediment transport in Figure 7, it can be found that the sediment transport in 2018 is greater than it was in 2019, which is obviously inconsistent with the sediment transport corresponded by turbidity. Therefore, it can be concluded that in the absence of an earthquake, the sediment transport in 2019 would be less than what it would have been in 2018. However, because of the 2018 Hokkaido Eastern Iburi Earthquake, a large amount of soil and sand entered into the river, and the bare land introduced by landslides, caused sediment transport to increase greatly in 2019. According to Figure 8 , it can be found that the correlation between turbidity and sediment transport before and after the 2018 Hokkaido Eastern Iburi Earthquake at Kyoei Station changed very significantly, and it portrays the grave impact of 2018 the Hokkaido Eastern Iburi Earthquake on sediment transport in the Atsuma River basin. 


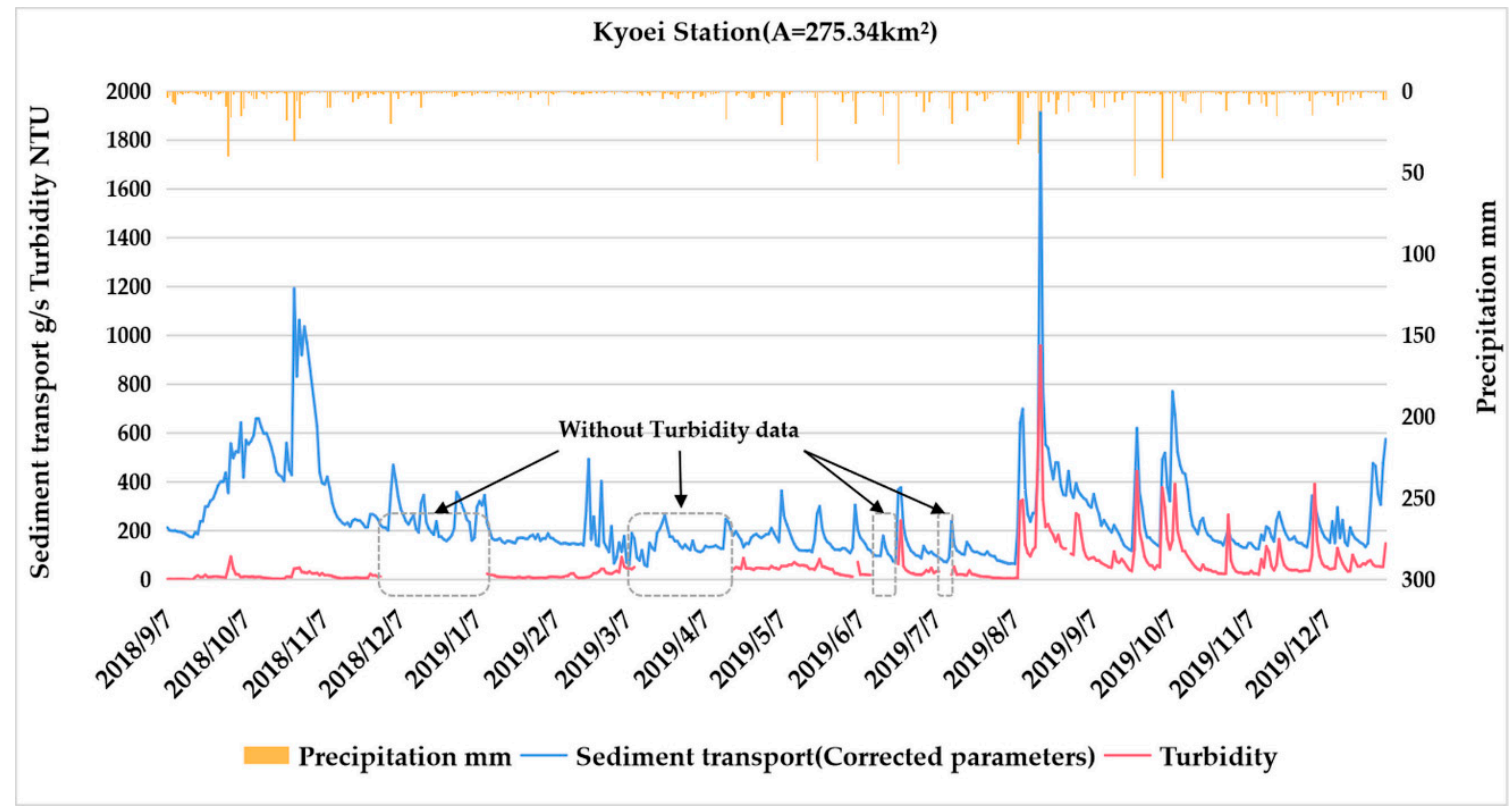

Figure 8. Comparison of turbidity and sediment transport (corrected parameters) after 2018 Hokkaido Eastern Iburi Earthquake at Kyoei station.

Due to the absence of observation sediment transport data of the Atsuma River basin, the SWAT-CUP software cannot be used to optimize the sediment transport parameters after the earthquake or correct the parameters by analyzing the error between the calculation sediment transport and observation sediment transport. In order to evaluate the increase in sediment transport after the 2018 Hokkaido Eastern Iburi Earthquake, according to previous research, field investigation, and the correlation between sediment transport and turbidity, this study corrected sediment transport parameters after the earthquake, including Channel cover factor $\left(\mathrm{CH}_{-} \mathrm{COV}\right)$, Linear re-entrained parameter for channel sediment routing (SPCO), Exponent of re-entrained parameter for channel sediment routing (SPEXP), Channel erodibility (CH_EROD). The landslides and collapse on both sides of the river channel caused by earthquake damaged the vegetation on the riverbank and enhanced the erosion ability of the river channel. The sediment directly entered the river channel which produced more sediment. By adjusting these sediment transport parameters, reproducing as much as possible the changes in the Atsuma River basin caused by the earthquake, the correlation between sediment transport and turbidity after the earthquake can be made as similar as possible to that before the earthquake.

Figure 8 shows the results obtained after using the corrected sediment parameters to simulate the process of sediment transport after the 2018 Hokkaido Eastern Iburi Earthquake. The correlation between turbidity and sediment transport before and after the 2018 Hokkaido Eastern Iburi Earthquake at Kyoei Station is shown in Figure 8. According to Figures 8 and 9, it can be observed that using corrected sediment transport parameters, the sediment transport simulation results improved greatly and the correlation between sediment transport and turbidity after the earthquake is more similar with that before the earthquake. The amount of sediment transport per unit rainfall before and after the 2018 Hokkaido Eastern Iburi Earthquake at Kyoei Station is shown in Table 5. It is roughly estimated that the amount of sediment transport per unit rainfall increased from 3.5 tons $/ \mathrm{mm} /$ year before the earthquake to 6.2 tons $/ \mathrm{mm} /$ year after the earthquake. Although there is no observation sediment transport data for calibration, the sediment transport increase can be roughly assessed. The predictions presented here should be viewed more as qualitative trends, rather than as accurate absolute numerical predictions. 


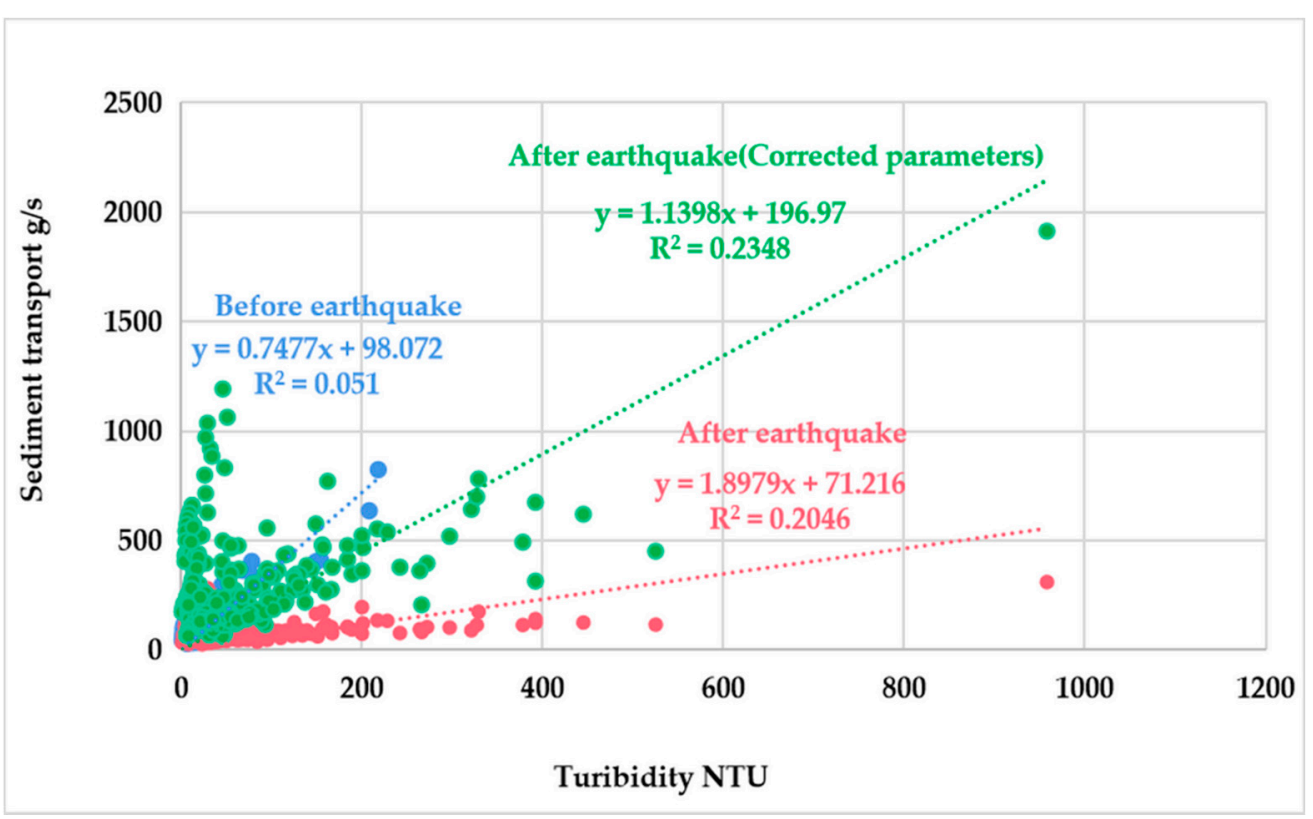

Figure 9. Correlation between turbidity with sediment transport before and after the 2018 Hokkaido Eastern Iburi Earthquake at Kyoei Station.

Table 5. The amount of sediment transport per unit rainfall before and after the 2018 Hokkaido Eastern Iburi Earthquake at Kyoei Station.

\begin{tabular}{cccc}
\hline Period & $\begin{array}{c}\text { Sediment Transport } \\
\text { in Total (tons) }\end{array}$ & $\begin{array}{c}\text { Precipitation in Total } \\
\mathbf{( m m )}\end{array}$ & $\begin{array}{c}\text { Ratio } \\
\text { (tons/mm/year) }\end{array}$ \\
\hline $2018.1-2018.8$ & 2755.3 & 1053.2 & 3.5 \\
$2018.10-2019.12$ & 9754.6 & 1261.6 & 6.2 \\
\hline
\end{tabular}

\section{Discussion}

By adjusting the parameters and considering the impacts of the reservoirs, the Soil and Water Assessment Tool (SWAT) model was used to reproduce the process of runoff and sediment transport before and after the earthquake in the Atsuma River basin.

For runoff, the high-precision simulation can be achieved by adjusting the runoff parameters and setting the warm-up period and calculation period. This study used the SWAT-CUP to analyze the runoff parameter sensitivity and modify parameters accordingly. Sensitivity analysis was performed to identify the most sensitive runoff parameters for the model calibration using the Global Sensitivity part of SWAT-CUP. The sensitive runoff parameters were automatically calibrated using the Sequential Uncertainty Fitting (SUFI-2) algorithm. The applicability of the SWAT model on runoff simulation in the Atsuma River basin was verified and a decent foundation for reproducing the sediment transport process in the Atsuma River basin was built.

Based on previous research, after the 2018 Hokkaido Eastern Iburi Earthquak and large-scale landslides, the safety factor under natural conditions in the Atsuma River basin is very large, which shows that there will be no slope landslides without rainfall. The sediments that increased after the earthquake are mostly produced by the erosion processes. It is reasonable to use the SWAT model to study the sediment transport in the Atsuma River basin after the earthquake.

For sediment transport, since there is no observation sediment transport data for the Atsuma River basin, the SWAT-CUP cannot be used for sensitivity analysis and correction of sediment parameters. Firstly, the simulation of the sediment transport process in the Atsuma River basin from 2018 to 2019 was performed based on high-precision runoff simulation and assuming that no earthquakes occurred in that period. By analyzing the change 
characteristics of turbidity before and after the earthquake and the correlation between turbidity and sediment transport, it can be inferred that the sediment transport in the Atsuma River basin has been increased greatly after the 2018 Hokkaido Eastern Iburi Earthquake. Next, in order to evaluate the increased sediment transport after the 2018 Hokkaido Eastern Iburi Earthquake. This study relies on previous research, field investigation, the correlation between sediment transport with turbidity and multiple simulation attempts, and then the sediment transport parameters after earthquake were chosen and corrected manually. The process of sediment transport after the earthquake was reproduced. To ensure the high rigor of this research, the predictions presented here should be viewed more as qualitative trends, rather than as accurate absolute numerical predictions. After performing calculations, it is roughly estimated that the amount of sediment transport per unit rainfall increased from 3.5 tons $/ \mathrm{mm} /$ year before the earthquake to 6.2 tons $/ \mathrm{mm} /$ year after the earthquake.

The SWAT model is powerful and can accurately simulate various processes in the basin. In the process of using the SWAT model, the accuracy of the data and the understanding of various parameters are very important. The SWAT model also has some limitations. For example, professional software such as GIS and ENVI are required to prepare geographic data, which increases the difficulty of use. The operation of the SWAT model also requires the user to have high hydrological knowledge, so it is difficult for beginners to get started quickly. Secondly, the SWAT model simulates various processes in the basin based on the input geographic data, meteorological data, and other data. The SWAT model is limited by the data and model structure that cannot fully reproduce the real situation of the basin, and it also has the same results with different parameters, which requires further optimization.

In this study, based on available observation data, the impact of 2018 Hokkaido Eastern Iburi Earthquake on the sediment transport in the Atsuma River basin within a year after was verified, and the long-term impacts need continuous research. In the meantime, large particles suspended in the river may not move quickly with the runoff and be deposited on the riverbed. Hence, to research the impact of the 2018 Hokkaido Eastern Iburi Earthquake fully on the Atsuma River channel, it is necessary to add upstream verification location.

\section{Summary}

In this study, the Soil and Water Assessment Tool (SWAT) model was used to evaluate the changes of sediment transport before and after the earthquake in the Atsuma River basin, the SWAT-CUP software was used to analyze runoff parameters sensitivity and optimize parameters. The process of runoff and sediment transport in the Atsuma River basin before and after the 2018 Hokkaido Eastern Iburi Earthquake were reproduced. The $\mathrm{R}^{2}$, NSE, and PBIAS were employed to evaluate the accuracy of simulation results. The main conclusions are as follows:

- On the basis of considering the operation of reservoirs, the SWAT model can simulate runoff process in the Atsuma River basin with high accuracy.

- By comparing the turbidity with sediment transport and analyzing turbidity change characteristics, it can be proved that sediment transport process characteristics in the Atsuma River basin before and after the 2018 Hokkaido Eastern Iburi Earthquake have been changed. The sediment transport increased greatly in the Atsuma River basin after the earthquake.

- Based on rough calculation, due to the impacts of the earthquake, the amount of sediment transport per unit rainfall increased from 3.5 tons $/ \mathrm{mm} /$ year before the earthquake to 6.2 tons $/ \mathrm{mm}$ /year after the earthquake.

Author Contributions: Methodology, Y.C. and M.N.; software, Y.C. and H.O.; investigation, M.N. and Y.C.; data curation, M.N., H.O. and Y.C.; writing-original draft preparation, Y.C.; writingreview and editing, Y.C., M.N. and H.O.; supervision, M.N.; funding acquisition, M.N. All authors have read and agreed to the published version of the manuscript. 
Funding: This research was funded by River Center of Hokkaido.

Institutional Review Board Statement: Not applicable.

Informed Consent Statement: Not applicable.

Data Availability Statement: Not applicable.

Acknowledgments: All authors thank the Hokkaido Regional Development Bureau (MLIT), Hokkaido prefecture, River Center for their help to accomplish this study.

Conflicts of Interest: The authors declare no conflict of interest.

\section{References}

1. Yilmaz, V.; Can, Y. Impact of knowledge, concern and awareness about global warming and global climatic change on environmental behavior. Environ. Dev. Sustain. 2020, 22, 6245-6260. [CrossRef]

2. Jyoteeshkumar, P.; Kiran, P.V.; Balaji, C. Chennai extreme rainfall event of 2015 under future climate projections using the pseudo global warming dynamic downscaling method. Curr. Sci. 2020, 118, 1968-1979. [CrossRef]

3. Anenberg, S.C.; Dutton, A.; Goulet, C.A.; Swain, D.L.; Van Der Pluijm, B. Toward a Resilient Global Society: Air, Sea Level, Earthquakes, and Weather. Earth's Future 2019, 7, 854-864. [CrossRef]

4. De Bruijn, J.A.; De Moel, H.; Jongman, B.; De Ruiter, M.C.; Wagemaker, J.; Aerts, J.C.J.H. A global database of historic and real-time flood events based on social media. Sci. Data 2019, 6, 1-12. [CrossRef] [PubMed]

5. China Earthquake Administration. Available online: https://www.cea.gov.cn/cea/xwzx/zyzt/index.html (accessed on 11 December 2020).

6. Faturay, F.; Sun, Y.Y.; Dietzenbacher, E.; Malik, A.; Geschke, A.; Lenzen, M. Using virtual laboratories for disaster analysis-A case study of Taiwan. Econ. Syst. Res. 2020, 32, 58-83. [CrossRef]

7. Liu, Q.F.; Yin, D.Y.; Wang, Z.C. Inversion of the rupture process and high-frequency radiation of the 2017 Jiuzhaigou earthquake, northeastern Tibetan Plateau. J. Asian Earth. Sci. 2020, 179, 300-318. [CrossRef]

8. Domenech, G.; Fan, X.M.; Scaringi, G.; Van Asch, T.W.J.; Xu, Q.; Huang, R.Q.; Hales, T.C. Modelling the role of material depletion, grain coarsening and revegetation in debris flow occurrences after the 2008 Wenchuan earthquake. Eng. Geol. 2019, $250,34-44$. [CrossRef]

9. Bastola, S.; Murphy, C.; Sweeney, J. The role of hydrological modelling uncertainties in climate change impact assessments of Irish river catchments. Adv. Water Resour. 2011, 34, 562-576. [CrossRef]

10. Butts, M.B.; Payne, J.T.; Kristensen, M.; Madsen, H. An evaluation of the impact of model structure on hydrological modelling uncertainty for streamflow simulation. J. Hydrol. 2004, 298, 242-266. [CrossRef]

11. Kasa, I.; Gelybo, G.; Horel, A.; Bakacsi, Z.; Toth, E.; Koos, S.; Dencso, M.; Deelstra, J.; Molnar, S.; Farkas, C. Evaluation of three semi-distributed hydrological models in simulating discharge from a small forest and arable dominated catchment. Biologia 2017, 72, 1002-1009. [CrossRef]

12. Karki, R.; Srivastava, P.; Veith, T.L. Application of the Soil and Water Assessment Tool(SWAT) at field scale:c categorizing methods and review of applications. Trans. ASABE 2020, 63, 513-522. [CrossRef]

13. Briak, H.; Mrabet, R.; Moussadek, R. Use of a calibrated SWAT model to evaluate the effects of agricultural BMPs on sediments of the Kalaya river basin (North of Morocco). Int. Soil Water Conserve. Res. 2019, 7, 176-183. [CrossRef]

14. Jodar-Abellan, A.; Valdes-Abellan, J.; Pla, C.; Gomariz-Castillo, F. Impact of land use changes on flash flood prediction using a sub-daily SWAT model in five Mediterranean ungauged watersheds (SE Spain). Sci. Total. Environ. 2019, 657, 1578-1591. [CrossRef] [PubMed]

15. Kamamia, A.W.; Mwangi, H.M.; Feger, K.H.; Julich, S. Assessing the impact of a multimetric calibration procedure on modelling performance in a headwater catchment in Mau Forest, Kenya. J. Hydrol.-Reg. Stud. 2019, 21, 80-91. [CrossRef]

16. Meng, X.Y.; Wang, H.; Lei, X.H.; Cai, S.Y.; Wu, H.J.; Ji, X.N.; Wang, J.H. Hydrological modeling in the Manas River Basin using soil and water assessment tool driven by CMADS. Teh. Vjesn. 2017, 24, 522-534. [CrossRef]

17. Martinez-Salvador, A.; Conesa-Garcia, C. Suitability of the SWAT Model for Simulating Water Discharge and Sediment Load in a Karst Watershed of the Semiarid Mediterranean Basin. Water Resour. Manag. 2020, 34, 785-802. [CrossRef]

18. Almendinger, J.E.; Murphy, M.S.; Ulrich, J.S. Use of the Soil and Water Assessment Tool to Scale Sediment Delivery from Field to Watershed in an Agricultural Landscape with Topographic Depressions. J. Environ. Qual. 2014, 43, 9-17. [CrossRef]

19. Francesconi, W.; Srinivasan, R.; Perez-Minana, E.; Willcock, S.P.; Quintero, M. Using the Soil and Water Assessment Tool (SWAT) to model ecosystem services: A systematic review. J. Hydrol. 2016, 535, 625-636. [CrossRef]

20. Kawamura, S.; Kawajiri, S.; Hirose, W.; Watanabe, T. Slope failures/landslides over a wide area in the 2018 Hokkaido Eastern Iburi earthquake. Soils Found. 2019, 59, 2376-2395. [CrossRef]

21. Osanai, N.; Yamada, T.; Hayashi, S.; Kastura, S.; Furuichi, T.; Yanai, S.; Murakami, Y.; Miyazaki, T.; Tanioka, Y.; Takiguchi, S Characteristics of landslides caused by the 2018 Hokkaido Eastern Iburi Earthquake. Landslides 2019, 16, 1517-1528. [CrossRef] 
22. Wang, F.R.; Fan, X.M.; Yunus, A.P.; Subramanian, S.S.; Alonso-Rodriguez, A.; Dai, L.X.; Xu, Q.; Huang, R.Q. Coseismic landslides triggered by the 2018 Hokkaido, Japan (M-w 6.6), earthquake: Spatial distribution, controlling factors, and possible failure mechanism. Landslides 2019, 16, 1551-1566. [CrossRef]

23. Fukuda, K.; Shibata, Y.; Sato, H.; Okabe, S. How the large-scale blackout following the 2018 Hokkaido Eastern Iburi earthquake impacted adolescents' sleep patterns. Sleep Biol. Rhythms 2020, 18, 351-354. [CrossRef]

24. Gou, T.; Huang, Z.C.; Zhao, D.P.; Wang, L.S. Structural Heterogeneity and Anisotropy in the Source Zone of the 2018 Eastern Iburi Earthquake in Hokkaido, Japan. J. Geophys. Res. Solid Earth 2019, 124, 7052-7066. [CrossRef]

25. Zang, C.; Ni, S.D.; Shen, Z.C. Rupture Directivity Analysis of the 2018 Hokkaido Eastern Iburi Earthquake and Its Seismotectonic Implication. Seismol. Res. Lett. 2019, 90, 2121-2131. [CrossRef]

26. Geospatial Information Authority of Japan. Available online: https://www.gsi.go.jp/top.html (accessed on 2 August 2020).

27. OpenStreetMap. Available online: https:/ / www.openstreetmap.org/\#map=10/42.7750/142.1062 (accessed on 4 July 2020).

28. Ito, Y.; Yamazaki, S.; Kurahashi, T. Geological features of landslides caused by the 2018 Hokkaido Eastern Iburi Earthquake in Japan. Geol. Soc. Lond. Spec. Publ. 2020, 501, 122-149. [CrossRef]

29. Katsumata, K.; Ichiyanagi, M.; Ohzono, M.; Aoyama, H.; Tanaka, R.; Takada, M.; Yamaguchi, T.; Okada, K.; Takahashi, H.; Sakai, S.; et al. The 2018 Hokkaido Eastern Iburi earthquake (M JMA= 6.7) was triggered by a strike-slip faulting in a stepover segment: Insights from the aftershock distribution and the focal mechanism solution of the main shock. Earth Planets Space 2019, 71, 1-8. [CrossRef]

30. Zhou, H.; Che, A.; Wang, L.; Wang, L. Investigation and mechanism analysis of disasters under Hokkaido Eastern Iburi earthquake. Geomat. Nat. Hazards Risk. 2021, 12, 1-28. [CrossRef]

31. Google Earth. Available online: https://www.google.com/earth/ (accessed on 10 September 2020).

32. Santhi, C.; Arnold, J.G.; Williams, J.R.; Dugas, W.A.; Srinivasan, R.; Hauck, L.M. Validation of the swat model on a large river basin with point and nonpoint sources. J. Am. Water Resour. Assoc. 2001, 37, 1169-1188. [CrossRef]

33. Nash, J.E.; Sutcliffe, J.V. River flow forecasting through conceptual models part I-A discussion of principles. J. Hydrol. 1970, 10, 282-290. [CrossRef]

34. Gupta, H.V.; Sorooshian, S.; Yapo, P.O. Status of automatic calibration for hydrologic models: Comparison with multilevel expert calibration. J. Hydrol. Eng. 1999, 4, 135-143. [CrossRef]

35. Moriasi, D.N.; Arnold, J.G.; Van Liew, M.W.; Bingner, R.L.; Harmel, R.D.; Veith, T.L. Model evaluation guidelines for systematic quantification of accuracy in watershed simulations. Trans. ASABE 2007, 50, 885-900. [CrossRef]

36. Benaman, J.; Shoemaker, C.A.; Haith, D.A. Calibration and validation of soil and water assessment tool on an agricultural watershed in upstate New York. J. Hydrol. Eng. 2005, 10, 363-374. [CrossRef]

37. Teixeira, L.C.; De Paiva, J.B.D.; Da Silva Pereira, J.E.; De Moura Lisbôa, R. Relationship between turbidity and suspended sediment concentration from a small hydrographic basin in Santa Maria (Rio Grande do Sul, Brazil). Int. J. River Basin Manag. 2016, 14, 393-399. [CrossRef]

38. Navratil, O.; Esteves, M.; Legout, C.; Gratiot, N.; Nemery, J.; Willmore, S.; Grangeon, T. Global uncertainty analysis of suspended sediment monitoring using turbidimeter in a small mountainous river catchment. J. Hydrol. 2011, 398, 246-259. [CrossRef]

39. Haimann, M.; Liedermann, M.; Lalk, P.; Habersack, H. An integrated suspended sediment transport monitoring and analysis concept. Int. J. Sediment Res. 2014, 29, 135-148. [CrossRef]

40. Sari, V.; Castro, N.M.D.; Pedrollo, O.C. Estimate of Suspended Sediment Concentration from Monitored Data of Turbidity and Water Level Using Artificial Neural Net works. Water Resour. Manag. 2017, 31, 4909-4923. [CrossRef]

41. Bright, C.; Mager, S.; Horton, S. Response of nephelometric turbidity to hydrodynamic particle size of fine suspended sediment. Int. J. Sediment Res. 2020, 35, 444-454. [CrossRef] 